\title{
Fish Tank Granuloma - a Case Report
}

\author{
Tijana BOLJEVIĆ 1 , Željko MIJUŠKOVIĆ ${ }^{1}$, Lidija KANDOLF SEKULOVIĆ1, \\ Biserka VUKOMANOVIĆ-ĐURĐEVIĆ²
}

${ }^{1}$ Department of Dermatology and Venereology, Faculty of Medicine, Military Medical Academy, Belgrade, Serbia

${ }^{2}$ Institute of Pathology and Forensic Medicine, Military Medical Academy, Belgrade, Serbia

*Correspondence: Tijana Boljević, Department of Dermatology and Venereology, Faculty of Medicine, Military Medical Academy, Belgrade, Serbia, E-mail: tijanaboljevic@yahoo.com

UDC 616.5-002:579.86

\begin{abstract}
Swimming-pool granuloma and fish tank granuloma refer to the infections caused by Mycobacterium marinum. After having been discovered in salt water fish in Philadelphia Aquarium and described in 1926, this skin infection was first reported in humans in 1951. It developed in people who had swum in contaminated swimming pools. M. marinum is a non-tuberculous, atypical mycobacterium, which is found on plants, soil and fish in freshwater and salt water worldwide. Humans become infected usually after trauma and contact with an aquatic environment. Infection is limited to the skin and usually occurs in healthy individuals, but in immunocompromised patients the infection may disseminate or spread to the subcutis and bone. The lesions usually appear as solitary nodules or plaques that may lead to suppurative ulcers after 2-3 weeks of incubation. Occasionally, there may be sporotrichoid spread along lymphatics. Its diagnosis is frequently delayed, probably because the infection is very rare and a history of aquatic exposure, which is present in the majority of cases, is often overlooked. Common misdiagnoses include fungal and parasitic infection, cellulitis, verrucous tuberculosis of the skin, gout, rheumatoid arthritis, a foreign body and a skin tumour. We present a case of a 39-year-old Caucasian male with a 12-month history of a single erythematous tender nodule on the right dorsal aspect of the right hand. Histopathological examination revealed longstanding suppurated granulomatous inflammation. The infection was not responsive to several courses of antibiotics until we introduced doxycycline capsules as monotherapy which led to complete remission after 5 months.
\end{abstract}

Key words: Mycobacterium marinum; Mycobacterium Infections; Skin Diseases, Bacterial; Granuloma; Hand Dermatoses; Doxycycline

\section{Introduction}

Mycobacterium marinum is a nontuberculous photochromogenic mycobacterium causing a disease in many fish species from cold or warm, fresh or salted water. Human infection follows the contact with fish or contaminated water. First described as "swimming-pool granuloma", nowadays M. marinum skin infection often results from inadequate aquarium maintenance and is called "fish tank granuloma". The infection is commonly limited to the skin of the limbs, but it can spread to deeper structures, resulting in tenosynovitis, arthritis, and osteomyelitis (4, 5). Surgery, antibiotics and cryotherapy have been recommended for the treatment of $M$. marinum infections, but none of these treatments has proved to be superior. Antibiotic efficacy and its correlation to in vitro suscep- tibility are unknown because cases were reported separately in the literature, no therapeutic trial has been done, and data on $\mathrm{M}$. marinum susceptibility are scarce (limited number of strains and antibiotics) $(6,7)$.

\section{Case 1}

A 39-year-old male patient reported an asymptomatic lesion on the right dorsal third metacarpophalangeal joint with 12 months of evolution. The lesion initially presented as a pustule on the dorsum of the right hand, with progression in the next few months to the plaque with a purulent discharge (Figure 1). Prior to consultations, the patient had received repeated prescriptions for topical corticosteroids, with no evidence of improvement. Skin biopsy was performed and his- 


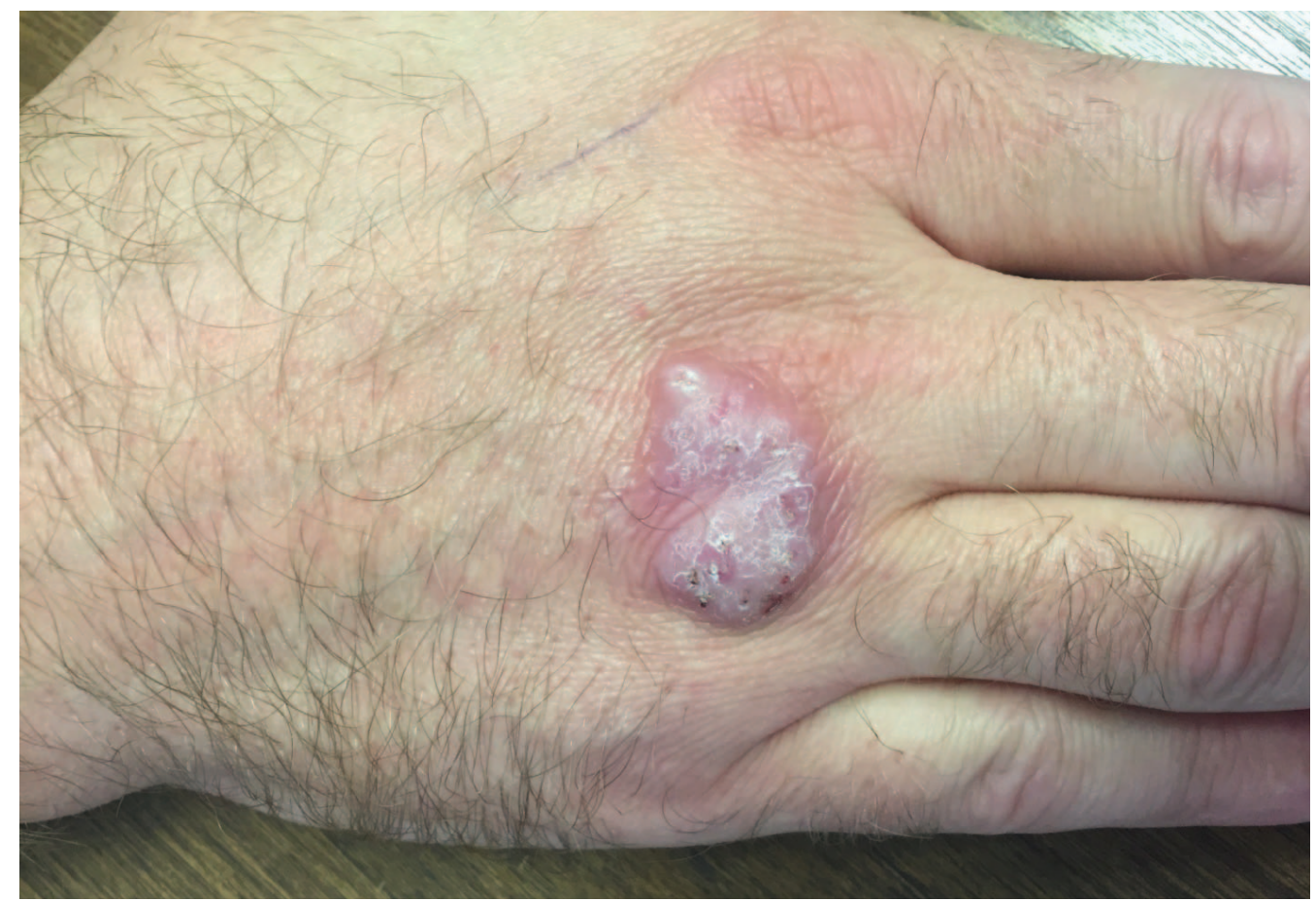

Figure 1. Clinical presentation of tender rough-whitish erythematous nodule on the dorsal side of the right hand

topathological investigation showed suppurative granulomatous inflammation, and he was treated with rifampicin and claritromycin, without improvement. After months of clinical evaluations by different specialists, the patient was admitted to our Department of Dermatology. Clinical examination did not reveal other skin/ mucosal lesions, reduced sensitivity, lymphonodopathy, nor any associated systemic manifestations. Having taken the detailed anamnesis (the patient had an aquarium), we performed the second biopsy, along with cultivations of the tissue for typical and atypical mycobacteria that confirmed infection with atypical mycobacteria. Antibiotic treatment with doxycycline caps. $200 \mathrm{mg} /$ daily was introduced and resulted in complete resolution of the lesion after 5 months (Figure 3).

\section{Discussion}

M. marinum is a non-tuberculosis mycobacterium living freely in an aquatic environment. It is responsible for the development of a distinctive cutaneous infection that may result in abraded skin, following the contact with the contaminated salt or fresh water or infected aquariums. M. marinum is an uncommon cause of skin infections. Therefore, a substanial delay has been observed between the appearance of the lesions and the correct diagnosis. The disease usually presents as a solitary, red to

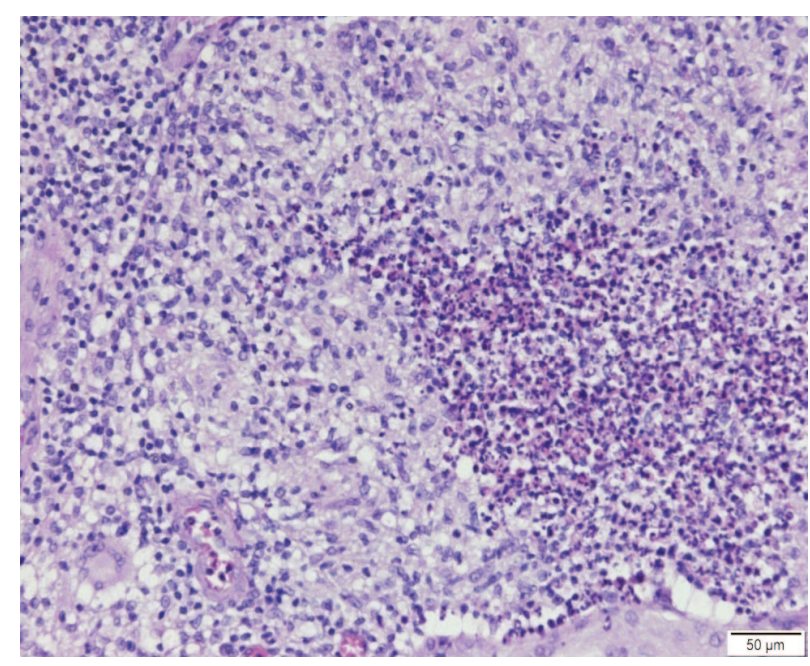

Figure 2. Histopatological examination showed an abscess in the center due to neutrophils and necrosis, with histiocytes, epithelioid cells and multinucleated giant cells, around the abscess (HE x50) 
Table 1. Treatment options for fish-tank granuloma*

\begin{tabular}{|c|c|c|}
\hline Type of lesion & Antibiotics & Duration \\
\hline Superficial (limited 1-3 lesions) & $\begin{array}{c}\text { Doxycycline } 200 \mathrm{mg} / \text { day [present case] } \\
\text { Clarithromycin } 500 \mathrm{mg} / \text { day [9] } \\
\text { Minocycline } 200 \mathrm{mg} / \text { day [8,9] } \\
\text { Ciprofloxacin } 1000 \mathrm{mg} / \text { day [8] } \\
\text { Trimethoprim-sulfamethoxazole 160/800 mg/day [12] } \\
\text { Amikacin } 400 \mathrm{mg} / \text { day [9] }\end{array}$ & $\begin{array}{c}2-12 \\
\text { months }\end{array}$ \\
\hline $\begin{array}{l}\text { Numerous lesions }(>3) \text {, Sporotrichoid } \\
\text { spread, deep infection }+ \text { skin involvement) }\end{array}$ & $\begin{array}{c}\text { Rifampicin } 600 \mathrm{mg} / \text { day + Ethambutol } 15-25 \mathrm{mg} / \text { day [11] } \\
\text { Rifampicin + Clarithromycin [13] } \\
\text { Rifampicin + Minocycline[13] } \\
\text { Surgical excision }\end{array}$ & $\begin{array}{c}2-12 \\
\text { months }\end{array}$ \\
\hline
\end{tabular}

*modified from Bhatty et al. [14]

violaceous papule and/or nodule evolving to a verrucous plaque that may ulcerate on the areas of trauma. The diagnosis of a skin M. marinum infection requires a high index of suspicion, a detailed exposure history, as well as the knowledge of laboratory growth characteristics of the organism $(4,8,9)$. Although the diagnosis was confirmed in our case by isolation and identification of the organism, in practice the diagnosis remains largely presumptive based on clinico-histological features and the response to treatment (10).

There have been many therapeutic modalities used effectively in the treatment of $M$.

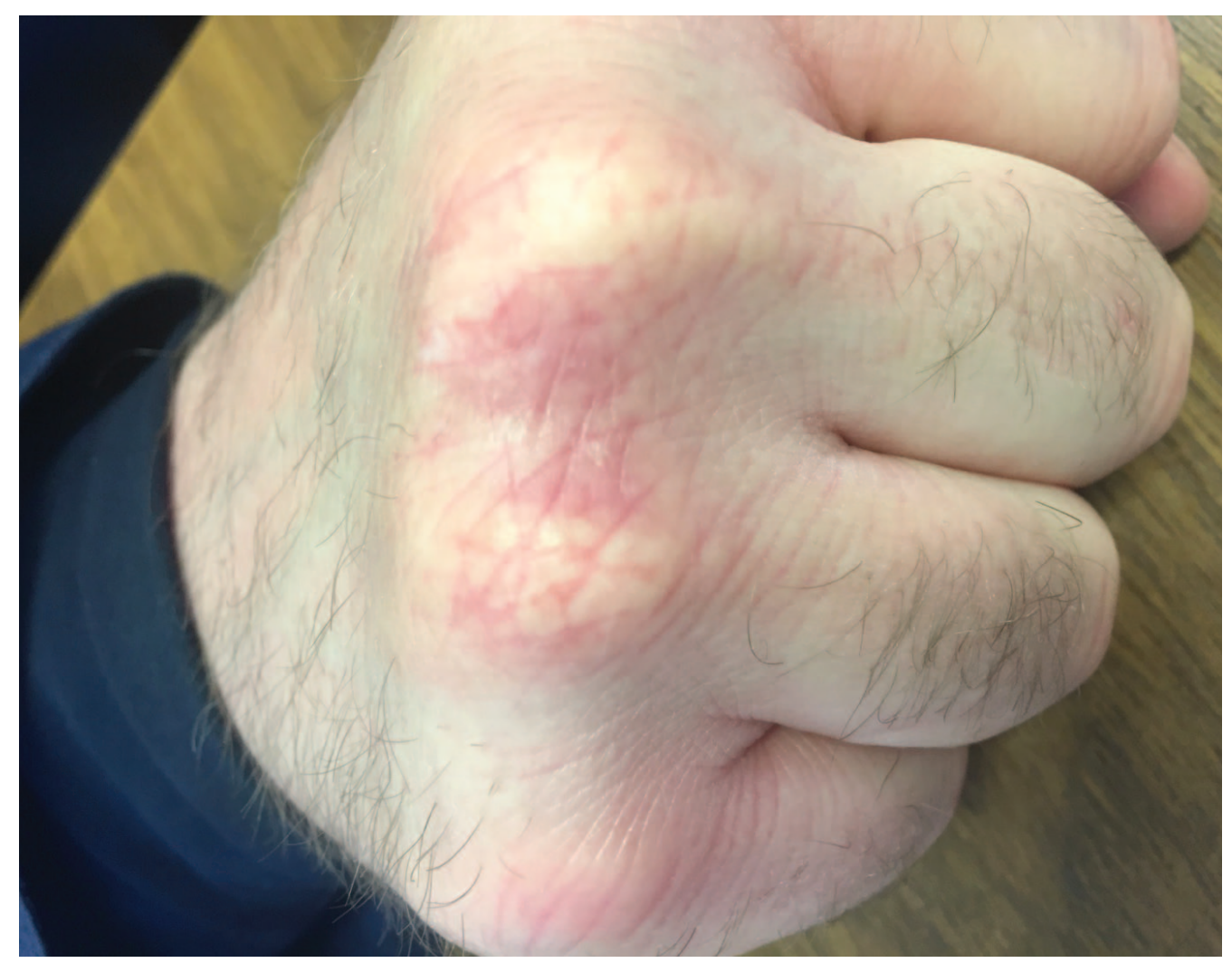

Figure 3. Clinical presentation at the end of antibiotic treatment 
marinum infections such as surgery, cryotherapy, and different antibiotic regimens. However, there is no proven treatment of choice because $\mathrm{M}$. marinum is a multidrug resistant species, and treatment is based primarily on personal experience and the preference of the individual researchers. Antibiotic monotherapy is usually, but not always, associated with infections limited to skin and soft tissue, and combinations of two or more antibiotics are used for more severe infections that spread into the local tissue. In superficial skin infections, doxycycline, clarithromicyin, minocycline and trimethoprim-sulfamethoxazole are used as monotherapy. A combined therapy with two or more drugs (e.g. rifampicin associated with ethambutol) might be required due to drug resistance. An isolated combination of rifampicin and ethambutol has been recommended in severe infections, including those with a sporotrichosis-like distribution. $(11,12)$ Treatment should be administered for at least 6 weeks up to 12 months, depending on the clinical evolution of lesion (13). In Table 1 treatment options for fish-tank granuloma are presented.

\section{Conclusion}

A detailed exposure history, high index of suspicion, as well as the knowledge of the laboratory growth characteristics of the organism is needed to establish the diagnosis of fish-tank granuloma. Antibiotic therapy should be tailored to the individual patient's reponse, and in resistant cases, surgery should also be considered.

\section{References}

1. Ang P, Rattana-Apiromyakij N, Goh CL. Retrospective study of Mycobacterium marinum skin infections. Int J Dermatol. 2000;39(5):343-7.

2. Palenque E. Skin disease and nontuberculous atypical mycobacteria. Int J Dermatol. 2000;39(9):659-66.

3. Huminer D, Pitlik SD, Block C, Kaufman L, Amit S, Rosenfeld JB. Aquarium-borne Mycobacterium marinum skin infection. Arch Dermatol. 1986; 122(6):698-703.

4. Gluckman SJ. Mycobacterium marinum. Clin Dermatol. 1995;13(3):273-6.

5. Edelstein H. Mycobacterium marinum skin infections. Arch Intern Med. 1994;154(12):1359-64.

6. Swift S, Cohen H. Granulomas of the skin due to Mycobacterium balnei after abrasions from a fish tank. N Engl J Med. 1962;267:1244-6.

7. Forsgren A. Antibiotic susceptibility of Mycobacterium marinum. Scand J Infect Dis. 1993;25(6):779- 82.

8. Saito H, Tomioka H, Sato K, Deiko S. In vitro and in vivo antimycobacterial activities of a new quinolone, DU-6859a. Antimicrob Agents Chemother. 1994; 38(12);2877- 82.

9. Wallace RJ, Wiss K. Susceptibility of Mycobacterium marinum to tetracyclines and aminoglycosides. Antimicrob Agents Chemother. 1981;20(5):610-2.

10. Jernigan JA, Farr BM. Incubation period and sources of exposure for cutaneous Mycobacterium marinum infection: case report and review of the literature. Clin Infect Dis. 2000;31(2):439-43.

11. García Acebes CR, Barchino Ortiz L, Aboín González S, Díaz Ley B, Ruiz Fernández P, Sánchez de Paz F. Infección por Mycobacterium marinum. Presentación de un nuevo caso y revisión de la literatura. Actas Dermosifiliogr. 2006;97(10):653-7.

12. Rallis E, Koumantaki-Mathioudaki E. Treatment of Mycobacterium marinum cutaneous infections. Expert Opin Pharmacother. 2007;8(17):2965-78.

13. Flondell M, Ornstein K, Björkman A. Invasive Mycobacterium marinum infection of the hand. J Plast Surg Hand Surg. 2013;47(6):532-4.

14. Bhatty MA, Turner DP, Chamberlain ST. Mycobacterium marinum hand infection: case reports and review of literature. Br J Plast Surg. 2000;53(2):161-5.

\section{Fish tank granuloma - prikaz slučaja}

\section{Sažetak}

Fish tank granuloma je infekcija izazvana atipičnom mikobakterijom (M. marinum), koja se može naći kako u slatkoj, tako i u slanoj vodi (najčešće u kontaminiranim akvarijumima i bazenima). Infekciju karakteriše spororastući plak ili nodus, a predilekciona mesta su uglavnom donji ili gornji ekstremiteti, a kod imunokompromitovanih pacijenata, infekcija se može diseminovati ili širiti na supkutano tkivo i kost. Dijagnoza se često kasno postavi, zato što je infekcija ovom bakterijom veoma retka, a česti su i slučajevi kada se infek- 
cija pogrešno dijagnostikuje kao gljivična i parazitarna infekcija, celulitis, tuberkuloza kože, giht ili reumatoidni noduli. Prikaz slučaja. Pacijent, starosti 39 godina, koji unazad 12 meseci ima bolno osetljiv, eritematozan nodus na dorzalnoj strani desne šake. Histopatološki je verifikovana supurativna granulomatozna inflamac- ija. Postejeća infekcija kože nije dala zadovoljavajući terapijski učinak tokom primene dvojne antibiotske terapije klaritromicin i rifampicinom, dok u terapiju nije uveden doksiciklin, kao monoterapija, što je rezultiralo kompletnom remisijom nakon pet meseci lečenja.

Ključne reči: Mycobacterium marinum; Mikobakterijske infekcije; Bakterijske kožne bolesti; Granulom; Dermatoze ruku; Doksiciklin 